\title{
Production-Oriented Approach and Its Implications for the Cultivation of Critical Thinking Skills in College English Instruction in Mainland China
}

\author{
Junhong Ren ${ }^{1} \&$ Na Wang ${ }^{1}$ \\ ${ }^{1}$ School of Foreign Languages, North China Electric Power University, Baoding, China \\ ${ }^{1}$ Correspondence: Junhong Ren, School of Foreign Languages, North China Electric Power University, Mailbox \\ 213, No.689 Huadian Road, Baoding 071003, Hebei Province, China. E-mail: rjh1003@126.com \\ Received: March 4, 2017 Accepted: April 6, 2018 Online Published: April 8, 2018 \\ doi: 10.5539/elt.v11n5p33 URL: http://doi.org/10.5539/elt.v11n5p33
}

\begin{abstract}
Absence of critical thinking skills is perceived to be a growing problem among many university students. The production-oriented approach, an initiative to college English instruction reform in mainland China, may offer a better solution to this problem. To cultivate critical thinking skills under this approach, reforms have to be implemented in teaching objectives, teaching materials, teaching approaches and assessment.
\end{abstract}

Keywords: critical thinking skills, production-oriented approach, college English instruction

\section{Introduction}

The cultivation of critical thinking skills is one of the core goals of higher education in Mainland China. According to the National Middle and Long-term Educational Reform and Development Plan (2010-2020) in China, universities should promote the all-round development of students, exploring their innovative spirit and improving their abilities in analyzing and solving problems. To this end, instructors should employ different teaching approaches, encouraging students to explore, to discuss, to question and to participate in classroom activities so as to create a sound environment for independent thinking, free exploration and innovation and enable students to learn independently.

However, contemporary college students are now faced with the fact that their critical thinking ability is weakening. Despite excellence of most students at memorization, recitation, and imitation, their performance in respect of analysis, reasoning, evaluation and synthesis is far from satisfactory (Zhang, 2012). Huang (1998, 2010) once described this phenomenon to be the absence of critical thinking skills. Many reasons may account for this unfavorable situation, among which the failure to lay stress on the cultivation of students' critical thinking skills in college English teaching is one that needs our special attention.

The cultivation of critical thinking skills should be an indispensible link in education (Siegel, 1984). The reason for this is obvious. Critical thinking skills could enable students to interpret phenomena from a broader perspective, make analysis and judgment multi-dimensionally, and put forward more solutions to problems. Taking into consideration the current situation we are now facing, it is essential that we lay emphasis on the cultivation of critical thinking skills in college English instruction.

\section{Critical Thinking Skills}

Critical thinking skills are now gaining increasing attention from the academics and administrators. Delphi project (1990) describes critical thinking to be composed of cognitive and affective dimensions. The cognitive abilities include six abilities: interpretation, analysis, evaluation, inference, explanation and self-regulation, among which analysis, evaluation and inference are the core skills. The affective dimensions consist of curiosity, confidence, open-mindedness, flexibility, fairness, honesty, prudence and understanding.

Bloom (1956) puts forth the cognitive taxonomy: knowledge, comprehension, application, analysis, synthesis, and evaluation. These six major categories of cognitive and processes start from the simplest to the most complex. Later, Anderson (2001) revises Bloom's taxonomy and proposes the Bloom-Anderson cognitive taxonomy. This taxonomy consists of remembering, understanding, applying, analyzing, evaluating and creating.

The Paul-Elder critical thinking framework (2006) is composed of three components: the elements of thought (reasoning); the intellectual standards and the intellectual traits. Elements of reasoning include purposes, 
questions, points of view, information, inferences, concepts, implications and assumptions. Intellectual standards that should be applied to the elements of reasoning refer to accuracy, clarity, relevance, logical sufficiency, precision, depth, significance, fairness, breadth. Intellectual traits of a cultivated critical thinker that intellectual standard must be applied to elements of reasoning in order to develop refer to humility, autonomy, fair-mindedness, courage, perseverance, empathy, integrity, and confidence in reasoning.

Wen (2009) puts forward a conceptual framework for the assessment of college students' critical thinking skills in China. The framework is composed of two levels: meta-critical thinking skills on the higher level and critical thinking skills on the lower level. The critical thinking skills consist of a cognitive component and an affective component. The cognitive component includes cognitive skills and standards which the cognitive skills are supposed to meet, and the affective component possesses some typical emotional attributes. According to Wen (2009), the cognitive skills include analysis, inference and evaluation while the standards consist of clarity, preciseness, relevance, logic, depth and flexibility. The affective dispositions refer to curiosity, openness, confidence, integrity and perseverance.

From different definitions of critical thinking skills, one can easily draw the conclusion that cognitive elements like analysis, inference and evaluation as well as affective elements like understanding seem to be the core of critical thinking skills.

\section{Current situation of Research on Critical Thinking Skills}

Critical thinking skills have been a major concern ever since the late $20^{\text {th }}$ century. Relevant research exploded at least two decades ago. Roughly, research concerning critical thinking in foreign countries mainly has two aims to fulfill, one is to construct the criteria for critical thinking assessment and the other is to cultivate learners' critical thinking in an effort to raise their critical awareness and enable them to combine learning with thinking (Ruan, 2012). Critical thinking skills in China, however, need further exploration since literature concerning the construction of the framework on the cultivation of critical thinking skills is rare to find. In addition, research concerning critical thinking skills usually takes English majors as subjects (Liu, 2009; Sun, 2011; Li, 2010; Li, 2011; Ruan, 2012; Wei, 2012) while non-English majors are seldom studied (Liu, 2013; Cai, 2017). Liu (2013) makes an attempt to build a model for developing students' critical thinking skills. This model includes flexible classroom atmosphere, content-based instruction, autonomous learning and assessment reform, with the aim of cultivating real talents possessing language skills and critical thinking skills. This initiative undoubtedly is of importance in consideration of our current college English instruction reform.

\section{Current Situation of College English Critical Teaching in Mainland China}

Although College English instruction in mainland China has undergone several major reforms, many problems still remain unsolved, among which the lack of interest in English learning on the part of the students is one that needs our special attention. According to a survey conducted by Cai (2010), 42.8 percent of 1282 teachers from 289 universities complain that their students are demotivated in college English learning. He attributes this phenomenon to inappropriate teaching goals and repetitive teaching content. Liu (2013), however, holds differing views. According to him, the reason why a large number of college students feel demotivated in English learning is because college English teaching has failed to stimulate their critical thinking, affective disposition and cognitive skills.

As far as I am concerned, these two views are not contradictory. Inappropriate teaching goals, repetitive teaching contents and improper assessment systems fail to motivate college students' interest and hence their critical thinking skills in English learning.

For a long time, our college English teaching has laid emphasis on the training of basic language skills in listening, speaking, reading and writing. In accordance with the teaching aims, teachers invest most of the class time into explanation of new words and sentence structures and students, accordingly, have to spend much of their time in mastery of vocabulary, grammar, etc. as is required. This popular teaching practice hinders the development of critical thinking skills since it centers on mechanical memorizing and imitation and fails to cultivate core critical thinking skills of analysis, inference and evaluation in students.

In addition, some of our teaching materials are hopelessly outdated. Since some materials have been written decades ago, some of the language usages that have been discarded by western societies are still learned by our students. Furthermore, some topics that are no longer heated issues are still discussed in our classes. Consequently, the teaching materials we are now using could neither arouse the students' interest nor meet their needs in English learning.

Finally, our current assessment system discourages cultivation of critical thinking skills. School authorities lay 
stress on the pass rate of nationwide English tests. Because of this, teachers would naturally emphasize the training of basic language skills, and students would spend most of their time practicing listening, speaking reading and writing in an effort to pass English tests and obtain sorts of language certificates. This test-oriented teaching practice fails to stimulate teachers' enthusiasm for teaching and students' interest in English learning.

Since the cultivation of critical thinking skills is absent in our teaching practice, many students find it a challenging task to lift their language comprehensive abilities to a higher level. They may find that their communicative competence has not well developed, that they are not good at analysis, inference and evaluation, and that logic and accuracy are lacking in their language.

\section{Cultivating Critical Thinking Skills under the Production-Oriented Approach}

We are now in an information era in which students are exposed to a large amount of information each and every day. Facing this information explosion, students have to learn to select from the sea of information the pieces that they are in need of. To this end, reforms have to be introduced in our current college English instruction.

To this end, we might as well introduce production-oriented approach (POA) proposed by Wen (2017). POA is conducive to the cultivation of students' critical thinking skills. POA is composed of three components: teaching principles, teaching hypothesis and teacher-mediated teaching process. The teaching principles which determine the direction and overall goals of classroom instruction refer to "learning-centered", "learning-using integrated" and "whole-person education". The teaching hypothesis which offers the theoretical basis for the teaching process includes "output-driven", "input-enabled" and "selective learning". And the teaching process that reflects and illustrates the principles while testing the hypotheses comprises three phases: motivating, enabling and assessing. Teacher's mediation is present at every phase.

\subsection{Teaching Principles}

Learning-centered principle proposes that different classroom activities be designed in accordance with different teaching objectives so as to guarantee effective learning. Classroom activities can take many forms: lectures, group discussions, and individual activities, etc. Teachers should choose the best forms to meet the teaching targets. Under this principle, teachers will have to spend much more time selecting and exploring the teaching materials; thereby design creatively class activities real to students' life so as to attract them to actively participate in class activities, and students will also have to devote more time to choosing and exploring the teaching materials, learning to use English freely through thinking, investigating, discussing and cooperating.

Learning-using integrated principle calls for an integration of learning and using in classroom instruction. Under this principle, texts, rather than being the purpose of English learning, has become the means by which students could fulfill their output tasks. That is, students have to select materials from other resources and after analysis, inference and synthesis, put these materials into practical use.

According to the whole-person education principle and the Higher Education Department of the Ministry of Education (2007), foreign language instruction has two aims to fulfill, one is to improve students' comprehensive English proficiency, and the other is to improve students' critical thinking, autonomous learning and cultural awareness. This philosophy has won wide support among scholars (Wang, 2011, 2013; Wang S.R. and Wang H.X., 2011; Wen, 2015). These two aims are not mutually exclusive. They can be achieved through careful selection of topics and teaching materials and skillful design of teaching activities. In this sense, the instructors have to invest some time to carefully select topics and materials that are conducive to the sound development of the students and that could raise students' awareness of intercultural communication. In addition, the instructors have to be very skillful in designing class activities, either by group work to enhance their collaborative spirit or by assessment to improve students' abilities to objectively evaluating their peers' strong points and weak ones.

\subsection{Teaching Hypothesis}

Output-driven hypothesis places emphasis on the importance of output in language learning. According to this hypothesis, output tasks are more likely to stimulate students' desire in and enthusiasm of English learning than input tasks do and therefore could enable the students to achieve better results.

Input-enabled hypothesis posits that better results could be yielded if instructors provide learners with appropriate language input tailored to the output tasks which are designed to meet the needs of students of different English levels.

Selective learning hypothesis posits that selective learning is more efficient than non-selective learning (Hanten et al., 2007; Miyawaki, 2012). "Selective learning" refers to the selection of useful information from the input material for deep processing, practice and memory in accordance with the requirements of the output tasks. 
These teaching hypotheses offer theoretical basis for the cultivation of critical thinking skills.

\subsection{Teaching Process}

The teaching process includes three phases: motivating, enabling and assessing. These phases are teacher-mediated in that teachers may play the roles of guide, design and scaffolding.

Teachers would introduce situations and topics concerning future studies and work which students may have not experienced but may perceive as possible occurrence. Students may realize the information gap in trying to accomplish the designed tasks, thereby arouse their interests and enthusiasm to use English with purpose in the specific context. Then, teachers inform the students of the communicative and language objectives and output tasks they are expected to fulfill. These language objectives are meant to serve the communicative goals, therefore words, phrases and language forms irrelevant to the communicative objectives will not be listed in the language goals. In the enabling phase, teachers provide description of the output tasks, decompose the tasks into subtasks and explicate the steps involved in completing the tasks. Students then carry on selective learning while teachers give instructions to them to make sure that they could select from the input the content, language forms and discourse structure needed to complete the output tasks. Finally, students put what has been selected from the input into practice while teachers offer instruction to students to make sure that they could apply what they've learned from selective materials to the completion of output tasks. After the output tasks being accomplished, assessments will be given toward their learning results of selective learning and practices in classroom and the results of the practices outside of classroom.

In conclusion, teachers should guide the students to learn how to observe, estimate, discover, compare, induce, associate, comprehend and memorize instead of imitating or reciting in English learning. And students need be enlightened to discover problems, ask questions and probe problems so that students can think with their heads, participate in discussions and learn English independently and self-reliantly.

\section{Conclusion}

Foreign language teaching in Mainland China has paid much attention to the introduction and memorization of the English knowledge, while ignores the cultivation of critical thinking abilities. Taking into consideration the core elements of critical thinking skills like analysis, inference and evaluation and their importance in the development of a student's cognitive abilities, it is essential that we highlight the development of students' critical thinking skills.

POA offers a theoretical framework that seems to work for the development of critical thinking skills in college English teaching in mainland China. Under this approach, teaching principles, teaching hypothesis and teaching process have to be altered so that the core critical thinking skills could be developed and enhanced. To this end, we need to make alterations in our teaching objectives, teaching materials, teaching process and assessment. In addition, teachers' roles need to be changed.

To begin with, school authorities have to be aware that English learning means more than passing examinations. Students are expected to acquire not only language competence but also inter-cultural communicative competence and critical thinking abilities. In response to this, traditional teaching objectives have to be revised in order to meet the needs of language learners and society. Emphasis should be laid on training critical thinking abilities and independent learning abilities, including abilities in analysis, inference and evaluation, etc..

Additionally, the teaching materials should be suitable to students' experiences, interests and needs because they are not only an important window for students to face the society and understand the world but also an integral carrier of natural science and art information. All the information should be helpful for students to learn other subjects (Xiahou, 2013).

Furthermore, instructors may design different forms of class actitivites to involve as many as, if not all students to investigation, discussion, exploration, etc., through which students can not only increase their language knowledge but also improve their critical thinking skills, cross-cultrual awareness and antonous learning.

Finally, school authorities and instructors concerned could encourage reforms in assessment, in which different forms other than tests could be included, like students' performance in using English to solve problems in selection and rearrangement of information, analysis, deduction, evaluation, etc.

\section{Acknowledgement}

This work is sponsored by "the Fundamental Research Funds for the Central Universities" (Grant \#2015MS70). 


\section{References}

Anderson, L. W., Krathwohl, D. R., Airasian, P. W., Cruikshank, K. A., Mayer, R. E., Pintrich, P. R., Raths, J., \& Wittrock, M. C. (2001). A Taxonomy for Learning, Teaching, and Assessing: A revision of Bloom's Taxonomy of Educational Objectives. New York: Pearson, Allyn \& Bacon.

Bloom, B. S. (Ed.). Engelhart, M. D., Furst, E. J., Hill, W. H., \& Krathwohl, D. R. (1956). Taxonomy of Educational Objectives, Handbook I: The Cognitive Domain. New York: David McKay Co Inc.

Cai, J. G. (2010). Some thoughts on reorientation of college English teaching in China. Foreign Language Teaching and Research, 4, 306 -308.

Cai, J. (2017). An analysis of the cultivation of students' critical thinking ability in College English Teaching. Modern Communication, 21, 141.

Hanten, G., Li, S., Chapman, P., Swank, J., Gamino, G., \& Roberson, G., \& Levin, H. (2007). Development of verbal selective learning. Developmental Neuropsychology, 1, 585-596. https://doi.org/10.1080/87565640701361112

Huang, Y. S. (2010). English major courses must be under reform: a revisit to the absence of critical thinking. Foreign Language World, 1, 11-16.

Huang, Y. S. (1998). Lack of critical thinking. Foreign Languages and Their Teaching, 7, 1-19.

Li, L. W. (2010). On the relationship between English language skills training and the development of critical thinking. Foreign Languages in China, 6, 68-73.

Li, L.W. (2011). Construction of a critical thinking-oriented English writing assessment model. Foreign Lanugages and Their Teaching, 1, 31-35.

Liu, Y. P. (2009). English speech training and the development of critical thinking. Educational Research on Foreign Languages \& Arts, 3, 49- 52, 66.

Miyawaki, K. (2012). Selective learning enabled by intention to learn in sequence learning. Psychological Research, 76, 84-96. https://doi.org/10.1007/s00426-011-0325-8

Pan, H. (2010). Absence of analytical thinking capacity among foreign language learners and critical thinking training. Journal of Heilongjiang College of Education, 7, 38-40.

Ruan, Q. Y. (2012). Building a conceptual framework for the development of English majors' critical literacy. Foreign Language World, 1, 37-43.

Sigel, I. E. (1984). A Constructive Perspective for Teaching Thinking. Educational Leadership, 42(3).

Sun, Y. Z. (2011). Toward a critical thinking-oriented curriculum for English majors. Foreign Lanugages in China, 3, 49-58.

Wang, S. R., \& Wang, H. X. (2011). On the state of college English teaching in China and its future development. Foreign Languages in China, 5, 1-5.

Wang, S. R. (2011). Some thoughts on college English teaching in China. Foreign Language Learning Theory and Practice, 1, 1-5.

Wang, S. R. (2013). Adhering to the scientific view of college English teaching reform. Foreign Language World, $6,9-22$.

Wei, X. B. (2012). An investigation of out factors that affect the development of English-mahir students' critical thinking skills. Journal of Xi'an International Studies University, 2, 72-75.

Wen, Q. F. (2009). Construction of a conceptual framework forassessing Chinese college students' critical thinking skills. Foreign Language World, 1, 37-43.

Wen, Q. F. (2017). Developing a theoretical system of production-oriented approach in language teaching. Foreign Language Teaching and Research, 4, 547-558.

Xia, H. F. S. (2013). English Curriculum and Instruction Theory. Beijing: Science Press.

Zhang, H. C. (2012). On the redemption of the weakening of contemporary college students' thinking ability, Journal of Teacher Education, 3, 179-181. 


\section{Copyrights}

Copyright for this article is retained by the author(s), with first publication rights granted to the journal.

This is an open-access article distributed under the terms and conditions of the Creative Commons Attribution license (http://creativecommons.org/licenses/by/4.0/). 